\title{
Educational peer group teenager to teenager's knowledge about bullying
}

\author{
Maria Ulfah Kurnia Dewi ${ }^{1}$ \\ ${ }^{1}$ Program Studi Pendidikan Profesi Kebidanan, Universitas Muhammadiyah Semarang, \\ Indonesia
}

\begin{abstract}
The phenomenon of bullying is not only seen from the point of view of the individual perpetrators and victims, but it focuses more on the social aspects behind the phenomenon. The formation and development of youth classes are a means to provide knowledge for adolescents about health. The youth class program must be carried out continuously in schools. The National Survey of Child and Adolescent Life Experiences (SNPHAR) by the Ministry of Women's Empowerment and Child Protection (KPPPA), 2018 revealed that 3 out of 4 adolescent children who had experienced one or more types of violence reported that the perpetrators of violence were friends or their peers. The purpose of this study was to determine the relationship between adolescent peer group education and adolescent knowledge about bullying. quantitative research with analytic survey design with the population is teenagers at the Ning Amriyah Soepardo Kendal Orphanage. The sample used is 30 respondents using total sampling. The research instrument used attendance data and questionnaires. The variables studied were adolescent peer group education and adolescent knowledge about bullying. The results showed that there was a relationship between adolescent peer group education and the level of adolescent knowledge about bullying (pvalue < $\alpha)$.
\end{abstract}

\section{Keywords: Education, Peer group, Teenager, Knowledge, Bullying}

Fenomena bullying tidak hanya dilihat dari sudut pandang individu pelaku dan korban, tetapi hal itu lebih menitikberatkan pada aspek sosial yang melatarbelakangi fenomena tersebut terjadi. Pembentukan dan pembinaan kelas remaja, merupakan sarana untuk memberikan pengetahuan bagi remaja tentang kesehatan. Program kelas remaja harus dilakukan secara berkelanjutan di sekolah. Survei Nasional Pengalaman Hidup Anak dan Remaja (SNPHAR) oleh Kementerian Pemberdayaan Perempuan dan Perlindungan Anak (KPPPA), 2018 mengungkapkan 3 dari 4 anak-anak remaja yang pernah mengalami salah satu jenis kekerasan atau lebih melaporkan bahwa pelaku kekerasan adalah teman atau sebayanya. Tujuan dari penelitian ini adalah untuk mengetahui hubungan antara Edukasi peer group remaja dengan pengetahuan remaja tentang bullying. penelitian kuantitatif dengan desain survey analitik dengan populasinya adalah remaja pada Panti Asuhan Ning Amriyah Soepardo Kendal. Sampel yang digunakan yaitu 30 responden dengan cara total sampling. Instrumen penelitan menggunakan data kehadiran dan kuesioner. Variabel yang diteliti adalah Edukasi peer group remaja dan pengetahuan remaja tentang bullying. Hasil penelitian menunjukkan bahwa terdapat hubungan antara Edukasi peer group remaja dengan tingkat pengetahuan remaja tentang bullying (pvalue $<\alpha$ ).

Kata Kunci: Edukasi, Peer group, Remaja, Pengetahuan, Bullying

\footnotetext{
Korespondensi Penulis : Maria Ulfah Kurnia Dewi (email mariaulfahkd82@gmail.com)
} 


\section{Pendahuluan}

Kehidupan sosial manusia terdiri atas beberapa fase dan tingkatan. Pada saat lahir, manusia sebagai individu tumbuh dan berkembang di lingkungan keluarga. Jika nilainilai yang ditanamkan oleh kedua orang tuanya diserap dengan baik, maka keterampilan sosial yang dimiliki oleh individu tersebut bisa menjadi lebih baik. Sebaliknya, apabila sosialisasi nilai-nilai yang ditanamkan keluarga kurang terserap oleh anak, maka bisa jadi perkembangan perilaku dan psikososialnya terhambat. Akibatnya, remaja mulai menunjukkan gejala-gejala patologis seperti kenakalan dan perilaku-perilaku beresiko lainnya, salah satunya adalah bullying (Zakiyah, Humaedi and Santoso, 2017).

Studi Program Penilaian Pelajar Internasional (PISA) tahun 2018 mengungkapkan 41\% pelajar berusia 15 tahun pernah mengalami bullying setidaknya beberapa kali dalam satu bulan. Survei Nasional Pengalaman Hidup Anak dan Remaja (SNPHAR) oleh Kementerian Pemberdayaan Perempuan dan Perlindungan Anak (KPPPA), 2018 mengungkapkan 3 dari 4 anak-anak remaja yang pernah mengalami salah satu jenis kekerasan atau lebih melaporkan bahwa pelaku kekerasan adalah teman atau sebayanya (Unicef Indonesia, 2018).
Pembentukan dan pembinaan kelas remaja, merupakan sarana untuk memberikan pengetahuan bagi remaja tentang kesehatan. Program kelas remaja harus dilakukan secara berkelanjutan di sekolah (Patimah, Mulyani and Silalahi, 2019).

Pada remaja awal kata peer biasanya berarti teman sebaya karena remaja awal secara khusus berhubungan dengan mereka yang memiliki usia yang sama. (peer $=$ teman setingkat dalam perkembangan).

Akibat pergaulan bersama peer group ini adalah mereka mengembangkan keterampilan sosial dan intimasi, mempertahankan hubungan dan rasa memiliki, mereka termotivasi untuk berhasil dan mendapat identitas diri. Karena remaja lebih banyak berada di luar rumah bersama dengan teman-teman sebaya sebagai kelompok, maka dapat dimengerti bahwa pengaruh teman-teman sebaya pada sikap, pembicaraan, minat, penampilan, dan perilaku yang sangat besar. Menjadi disukai dan diterima adalah penting pada masa remaja ini, karena menjadi prasyarat untuk mendapatkan feedback dan dapat mencoba gaya hubungan atau kepribadian yang berbeda-beda dari masa ke masa.

Penolakan dan penerimaan teman sebaya serta akibat-akibat yang ditimbulkannya 
merupakan hal yang sangat penting sebab menciptakan perilaku dan bentuk-bentuk tingkah laku yang akan dibawa oleh remaja pada masa dewasa. Penerimaan sosial dapat dicapai jika remaja bisa menyesuaikan diri terhadap harapan-harapan yang ada dalam kelompok tempat remaja tersebut ingin mendapatkan identitas (Kartika and Nisfiannoor, 2017).

Kata bullying berasal dari Bahasa Inggris, yaitu dari kata bull yang berarti banteng yang senang merunduk kesana kemari. Dalam Bahasa Indonesia, secara etimologi kata bully berarti penggertak, orang yang mengganggu orang lemah.

Tindakan bullying merupakan salah satu permasalahan serius yang pada umumnya dihadapi oleh anak-anak dan remaja di berbagai belahan dunia, tak terkecuali di Indonesia. United Nations Educational, Scientific, and Cultural Organization/ UNESCO (2019) sendiri mendefinisikan bullying sebagai perilaku agresif yang melibatkan tindakan negatif yang tidak diinginkan, dilakukan ulang secara terus menerus, dan adanya ketidakseimbangan daya dan kekuatan antara pelaku atau para pelaku dan korban. Dalam laporannya, UNESCO menyebutkan bahwa hampir satu dari tiga siswa atau sekitar 32\% telah mengalami bullying di sekolah yang dilakukan oleh teman-teman sekolahnya paling tidak sekali dalam sebulan terakhir. Lebih dari satu dari tiga siswa (36\%) telah terlibat dalam perkelahian fisik dengan siswa lain dan hampir satu dari tiga siswa (32.4\%) pernah diserang paling tidak sekali dalam setahun terakhir (United Nations Educational, 2019).

Kondisi bullying yang terjadi di Indonesia pun tidak jauh berbeda, bahkan persentase siswa yang mengalami bullying lebih tinggi dibandingkan persentase secara keseluruhan yang dituliskan dalam laporan UNESCO sebelumnya. Menurut data hasil riset PISA (Programme for International Students Asessment) pada tahun 2018, Indonesia sendiri menempati urutan tertinggi kelima di dunia dengan jumlah murid yang mengalami bullying yaitu sebesar 41,1\% (Unicef Indonesia, 2018).

Beberapa penelitian menunjukkan bahwa intervensi psikososial yang melibatkan psikiater, satu perawat psikiatri, dan profesional kesehatan lainnya (misalnya, pekerja sosial, spesialis pendidikan, atau terapis seni) setidaknya sama efektifnya dengan perawatan rawat inap untuk pengobatan remaja yang mencoba bunuh diri (Latimer, Gariépy and Greenfield, 2014).

Pengetahuan atau kognitif merupakan domain yang sangat penting dalam membentuk tindakan seseorang (overt behavior). Bukti 
penelitian mengungkapkan bahwa perilaku yang didasari oleh pengetahuan akan lebih langgeng daripada perilaku yang tidak didasari oleh pengetahuan. Proses adopsi perilaku baru (berperilaku baru) dalam diri seseorang terjadi berurutan, yakni awareness (kesadaran), interest (ketertarikan), evaluation (pertimbangan). Apabila penerimaan perilaku baru atau adopsi perilaku melalui proses seperti ini didasari oleh pengetahuan, kesadaran, dan sikap yang positif maka perilaku tersebut akan bersifat langgeng (long lasting). Sebaliknya apabila perilaku itu tidak didasari oleh pengetahuan dan kesadaran maka tidak akan berlangsung lama. Pemberian informasi-informasi tentang cara-cara mencapai hidup sehat, cara pemeliharaan kesehatan, cara menghindari penyakit, dan sebagainya akan meningkatkan pengetahuan masyarakat tentang hal tersebut. Pengetahuan akan menimbulkan kesadaran mereka dan akan menyebabkan orang berperilaku sesuai dengan pengetahuan yang dimilikinya itu. Hasil atau perubahan perilaku dengan cara ini memakan waktu lama, tetapi perubahan yang dicapai akan bersifat langgeng karena didasari oleh kesadaran mereka sendiri (bukan karena paksaan). Suatu sikap belum otomatis terwujud dalam suatu tindakan (overt behaviour).

\section{Metode}

Jenis penelitian ini merupakan penelitian analitik. Penelitian ini dilakukan dengan pendekatan cross-sectional. Tempat penelitian dilaksanakan di Panti Asuhan Ning Amriyah Supardo Kendal pada bulan Mei-Juni 2021. Teknik pengambilan sampel menggunakan total sampling. Jumlah sampel dalam penelitian ini adalah 30 orang. Analisis menggunakan uji non parametrik dengan data kategorik tidak berpasangan. Dalam analisis ini dilakukan dengan pengujian statistik yaitu dengan uji Chi Square.

\section{Hasil dan Pembahasan}

Hasil analisis menunjukkan terdapat hubungan antara Edukasi peer group remaja dengan tingkat pengetahuan remaja tentang bullying (pvalue $<\alpha$ ).

Kelompok terbentuk secara spontan, tetapi kelompok tersebut juga dapat terbentuk secara formal, sebagai contoh adalah kelompok yang ada di kelas-kelas sekolah. Kelompok teman sebaya merupakan lingkungan sosial pertama di mana remaja belajar untuk hidup bersama orang lain yang bukan anggota keluarganya. Lingkungan teman sebaya merupakan suatu kelompok yang baru, yang memiliki ciri, norma, kebiasaan yang jauh berbeda dengan apa yang ada dalam lingkungan keluarga remaja. Kelompok teman 
sebaya merupakan sumber afeksi, simpati dan pemahaman, pembimbing secara moral, tempat untuk bereksperimen, persiapan untuk mendapatkan otonomi dan tidak tergantung dengan orang tua.

Kelompok teman sebaya tampaknya sangat berpengaruh jika tingkahlaku yang tepat tidak terlalu nyata. Misalnya pemilihan jenis musik dan pakaian sangat bersifat subjektif karena remaja menjadi salah satu anggota dari kelompok teman sebayanya Sebagai kebutuhan untuk diakui dan diterima selama remaja, kelompok teman sebaya menjadi salah satu wakil yang paling penting dalam bersosialisasi.

Penerimaan oleh orang lain sangat tinggi pada daftar minat banyak remaja. Tidak seperti kebanyakan definisi populer, secara luas para remaja mencari teman sebaya untuk menjadi teman dan diakui oleh mereka. Tetapi para remaja lebih menikmati penerimaan, dalam arti disukai oleh sebagian besar teman sebayanya. Penerimaan sosial mempunyai arti adanya seseorang dalam kelompok yang berkeinginan untuk memberikan penghargaan pada orang lain dalam hubungan yang lebih dekat.

Selama remaja memberikan kesenangan pada remaja lainnya dalam hubungan yang memiliki penghargaan dan bersifat positif saja, maka remaja tersebut akan diterima dalam kelompoknya. Keinginan remaja untuk ikut serta dalam aktivitas sosial dan berpakaian dan berbicara untuk diterima secara sosial sangat penting.

Remaja menemukan penerimaan kelompok teman sebaya dan popularitas dengan menyesuaikan diri, berprestasi, dan berpartisipasi dalam aktivitas sekolah, mengembangkan dan menunjukkan kualitas pribadi yang orang lain suka dan mempelajari kemampuan sosial yang dapat menjamin penerimaan. Beberapa remaja menemukan penerimaan melalui tingkah laku menyimpang yang dapat diterima oleh kelompok-kelompok tertentu.

Remaja memiliki nilai dalam menerima atau tidak menerima anggota-anggota berbagai kelompok sebaya. Tidak ada satu sifat atau pola perilaku khas yang menjamin penerimaan sosial selama masa remaja. Penerimaan bergantung pada sekumpulan sifat dan pola perilaku, yaitu sindroma penerimaan - yang disenangi remaja dan dapat menambah gengsi dari kelompok teman sebaya yang diidentifikasinya. Demikian pula, tidak satu sifat atau pola perilaku yang menjauhkan remaja dari teman-teman sebayanya. Namun ada pengelompokan sifat, yaitu sindroma alienasi yang merupakan sindrom yang membuat orang lain tidak menyukai dan menolaknya. 
Dalam kelompok teman sebaya, merupakan kenyataan adanya remaja yang diterima dan ditolak, yang disebabkan oleh beberapa faktor. Faktor-faktor yang menyebabkan seorang remaja diterima. Faktor-faktor yangmenyebabkan seorang remaja diterima: (1) Matang, terutama dalam hal pengendalian emosi serta kemauan untuk mengikuti aturan-aturan; (2) Kemampuan berpikir seperti mempunyai inisiatif, banyak memikirkan kelompok dan mengemukakan pendapatnya; (3) Sikap, sifat, perasaan meliputi: bersikap sopan, memperhatikan orang lain, penyabar atau menahan marah jika berada dalam keadaan yang tidak menyenangkan dirinya. Sedangkan menurut Hurlock, sikap yang tenang, gembira akan menimbulkan kesan yang menyenangkan ; (4) Kepribadian seperti jujur dan dapat dipercaya, bertanggung jawab dan suka menjalankan pekerjaannya, mentaati peraturanperaturan kelompok, mampu menyesuaikan diri secara tepat dalam berbagai situasi dan pergaulan sosial; (5) Pemurah, atau tidak pelit, atau tidak kikir, suka bekerjasama dan membantu anggota kelompok; (6) Reputasi sebagai seorang yang sportif dan menyenangkan; (7) Perilaku sosial yang ditandai oleh kerjasama, tanggung jawab, panjang akal, kesenangan bersama orang-orang lain, bijaksana dan sopan.
Akibat yang menimbulkan rasa kecewa, yang akan membuat seorang remaja bertingkah laku agresif maupun yang bersifat pengunduran diri seperti; melamun, menyendiri, suka berdebat, suka memfitnah, atau mungkin menjadi pencuri. Remaja yang memiliki kesulitan meregulasikan kemarahannya dan menghambat agresinya, dalam jangka waktu panjang, gagal diterima oleh peer group. Sedangkan remaja yang bisa meregulasikan keinginan marahnya dengan cara sosialisasi yang lebih baik akan dihubungkan dengan penerimaan yang lebih baik oleh peer group (Kartika and Nisfiannoor, 2017).

Hal ini sejalan dengan penelitian yang dilakukan oleh Ulfatun (2021) bahwa edukasi antibullying dapat meningkatkan pengetahuan dan pemahaman siswa mengenai bullying sehingga mereka dapat mengaplikasikannya dalam kehidupan sekolahguna mewujudkan sekolah anti bullying (Ulfatun et al., 2021).

Perilaku bullying merupakan hambatan besar bagi anak untuk mengaktualisasikan diri. Penindasan perilaku dapat menyebabkan perasaan menjadi tidak aman dan tidak nyaman, ketakutan dan perasaan terintimidasi, harga diri rendah, kesulitan berkonsentrasi dalam belajar, tidak ingin bersosialisasi dengan orang lain dan kesulitan berkomunikasi. Penyebab bullying memiliki kepercayaan diri yang berlebihan 
dengan harga diri yang tinggi, cenderung agresif dengan provilent perilaku, biasanya kekerasan, mudah tersinggung dan impulsif, memiliki toleransi yang rendah terhadap frustrasi, sedangkan dampak pada korban sedang stres, marah, dan penurunan IQ dan prestasi di sekolah (Nauli, Jumaini and De Laura, 2019).

Tabel 1. Edukasi peer group remaja dengan tingkat pengetahuan remaja tentang bullying

\begin{tabular}{|c|c|c|c|c|c|c|c|}
\hline \multirow{3}{*}{$\begin{array}{c}\text { Kehadiran } \\
\text { Pendkes Peer } \\
\text { Group Remaja }\end{array}$} & \multicolumn{4}{|c|}{$\begin{array}{c}\text { Tingkat Pengetahuan Remaja } \\
\text { tentang Bullying }\end{array}$} & \multirow{2}{*}{\multicolumn{2}{|c|}{ Total }} & \multirow{3}{*}{ P-value } \\
\hline & \multicolumn{2}{|c|}{$\mathrm{Ya}$} & \multicolumn{2}{|c|}{ Tidak } & & & \\
\hline & $\mathrm{F}$ & $\%$ & $\mathrm{~F}$ & $\%$ & $f$ & $\%$ & \\
\hline Tidak hadir & 11 & 36,7 & 4 & 13,3 & 15 & 100 & \\
\hline Hadir & 4 & 13,3 & 11 & 36,7 & 15 & 100 & 0,028 \\
\hline Total & 15 & 50 & 15 & 50 & 82 & 100 & \\
\hline
\end{tabular}

\section{Kesimpulan}

Terdapat hubungan antara Edukasi peer group remaja dengan pengetahuan remaja tentang bullying (pvalue $<\alpha$ ). Diharapkan pihak sekolah mengembangkan sekolah anti-bullying program untuk mencegah dan mengurangi perilaku intimidasi. Saran untuk sekolah untuk menangani kasus bullying di sekolah adalah untuk menerapkan kebijakan anti-intimidasi, optimalkan peran unit kesehatan sekolah dengan bekerjasama dengan perawat kesehatan mental mengusulkan pendirian sekolah kesehatan mental satuan. Perawat dapat memiliki peran penting dalam merawat siswa yang terintimidasi karena perawat sekolah memiliki perbedaan hubungan dengan siswa dibandingkan dengan pegawai sekolah lainnya.

\section{Daftar Pustaka}

Kartika, Y. and Nisfiannoor, M. (2017) 'Hubungan Antara Regulasi Emosi Dan Penerimaan Kelompok Teman Sebaya Pada Remaja', Jurnal Psikologi, 2(2), pp. 160-178.

Latimer, E. A., Gariépy, G. and Greenfield, B. (2014) 'Cost-effectiveness of a rapid response team intervention for suicidal youth presenting at an emergency department', Canadian Journal of Psychiatry, 59(6), pp. 310-318. doi: 10.1177/070674371405900604.

Nauli, F. A., Jumaini, J. and De Laura, D. (2019) 'Analysis of Bullying Case Problem in Junior High School', Jurnal Keperawatan Soedirman, 14(2). doi: 10.20884/1.jks.2019.14.2.996.

Patimah, S., Mulyani, N. and Silalahi, U. A. (2019) 'Kelas Remaja ( Persiapan Pra Nikah ) Upaya Pembentukan Generasi Berencana Di Kelurahan Cikalang', Edukasi Masyarakat Sehat Sejahtera (EMaSS) : Jurnal Pengabdian kepada Masyarakat, 1(2), pp. 102-106. doi: 10.37160/emass.v1i2.306.

Ulfatun, T. et al. (2021) 'Edukasi Anti Bullying Bagi Guru Dan Siswa Smp Muhammadiyah Butuh 
Purworejo', Jurnal Pengabdian Masyarakat Berkemajuan, 4(April), pp. 165-169. Available at: http://journal.ummat.ac.id/index.php/jpmb /article/view/4260.

Unicef Indonesia (2018) Perundungan di indonesia: Fakta-fakta Kunci, Solusi, dan Rekomendasi.

United Nations Educational, S. and C. O. (2019) 'Behind the numbers: Ending school violence and bullying', Sustainable Development Goals: Education 2030, pp. 1-74. Available at:

https://unesdoc.unesco.org/ark:/48223/pf0 000366483.

Zakiyah, E. Z., Humaedi, S. and Santoso, M. B. (2017) 'Faktor Yang Mempengaruhi Remaja Dalam Melakukan Bullying', Prosiding Penelitian dan Pengabdian kepada Masyarakat, 4(2), pp. 324-330. doi: 10.24198/jppm.v4i2.14352. 